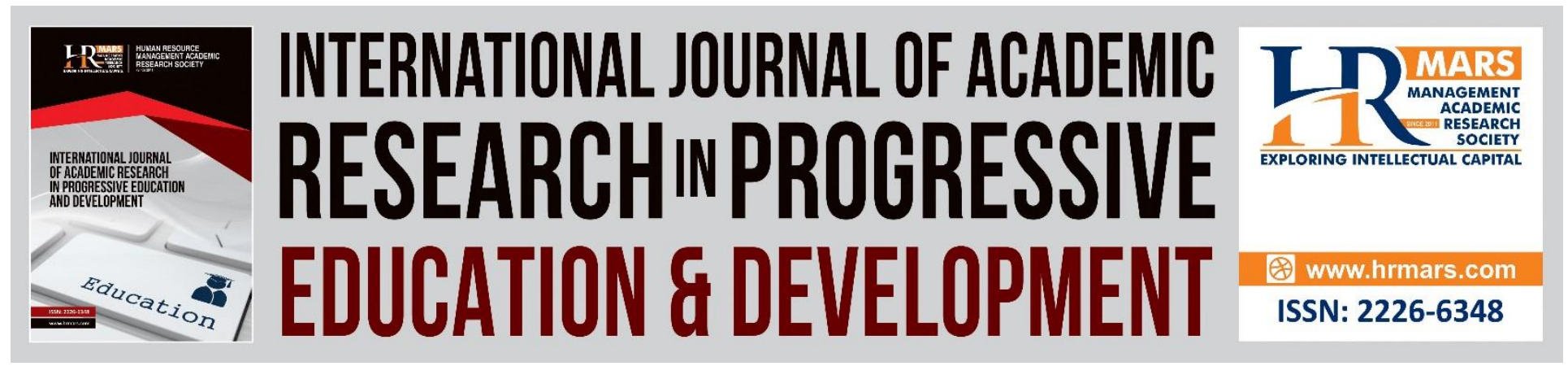

\title{
Drop-off and Pick-up Zone in Selected Primary School in Selangor
}

Sharifah Allyana SMR, Nurulhuda J, Nur Zarifah H, Azzuhana R

To Link this Article: http://dx.doi.org/10.6007/IJARPED/v9-i3/8261

DOI:10.6007/IJARPED/v9-i3/8261

Received: 12 October 2020, Revised: 10 November 2020, Accepted: 01 December 2020

Published Online: 11 December 2020

In-Text Citation: (SMR, 2020)

To Cite this Article: SMR, S. A. (2020). Drop-off and Pick-up Zone in Selected Primary School in Selangor. International Journal of Academic Research in Progressive Education and Development, 9(4), $138-144$.

Copyright: (C) 2020 The Author(s)

Published by Human Resource Management Academic Research Society (www.hrmars.com)

This article is published under the Creative Commons Attribution (CC BY 4.0) license. Anyone may reproduce, distribute, translate and create derivative works of this article (for both commercial and non-commercial purposes), subject to full attribution to the original publication and authors. The full terms of this license may be seen at: http://creativecommons.org/licences/by/4.0/legalcode

Vol. 9(3) 2020, Pg. 138 - 144

http://hrmars.com/index.php/pages/detail/IJARPED

JOURNAL HOMEPAGE

Full Terms \& Conditions of access and use can be found at http://hrmars.com/index.php/pages/detail/publication-ethics 


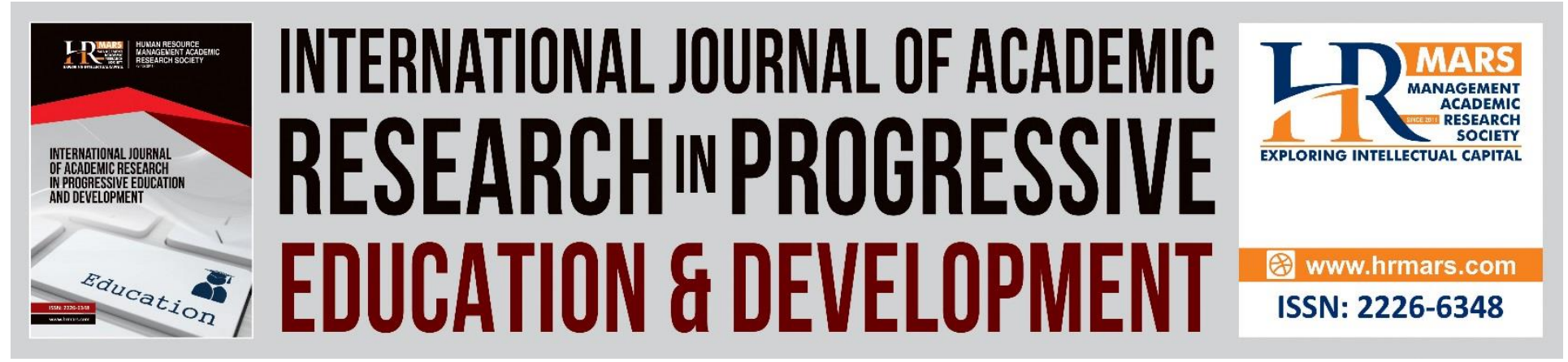

\title{
Drop-off and Pick-up Zone in Selected Primary School in Selangor
}

\author{
Sharifah Allyana SMR, Nurulhuda J, Nur Zarifah H, Azzuhana R \\ Malaysian Institute of Road Safety Research, Malaysia
}

\begin{abstract}
Statistics from Royal Malaysian Police (RMP) show that there were 259 accidents that occurred in school areas. One of the facilities to improve school children safety in school area is drop-off and pick-up zone. Drop-off and pick-up zone in school zone is defined as an area beyond the road reserve or within the school boundary that is dedicated for dropping off and picking up school children by private vehicles, vans and school buses. The study objectives are to identify the availability of designated Drop-Off and Pick-Up (D\&P), to assess the utilization of designated D\&P and to determine the trend of dropping off student within the selected primary school zone in Selangor. From the study it was found that out of 30 schools, D\&P are only available at 11 schools. In terms of utilization of D\&P at these schools, $52 \%$ of the observed school children used this facility. At school with D\&P also the remaining school children were picked up by their vehicles outside the D\&P area with $31 \%$ at nearside of the school and $17 \%$ at the far side of the school. In this study, it shows that the D\&P utilization for dropping and picking up school children can be further increase if parents/bus drivers do not wait in D\&P. With the high and the effective D\&P utilization, it will lower the risk of school children involved in an accident while crossing the road.
\end{abstract} Keywords: School, Children, Safety, Drop-Off, Pick-Up.

\section{Introduction}

The increase in the number of road accidents among the school children raised concerns by parents, especially when children are out of their supervision. A total of $85 \%$ of the overall primary and secondary schools in Malaysia were found to be at high risk because the students are exposed to road accidents (Utusan Malaysia, 2009). The risk will increase if the schools are located near the main road where the high traffic flow can cause the student more prone to accidents as evidently shown in Table 1. Statistics from Royal Malaysian Police (RMP) show that there were 228 accidents that occurred in school areas. One of the facilities to improve school children safety in school area is drop-off and pick-up zone. Drop-off and pick-up zone in school zone is defined as an area beyond the road reserve or within the school boundary that is dedicated for dropping off and picking up school children by private vehicles, vans and school buses. 
INTERNATIONAL JOURNAL OF ACADEMIC RESEARCH IN PROGRESSIVE EDUCATION AND

DEVELOPMENT

Vol. 9, No. 3, 2020, E-ISSN: 2226-6348 @ 2020 HRMARS

The study objectives are to identify the availability of designated Drop-Off and Pick-Up (D\&P), to assess the utilization of designated D\&P and to determine the trend of dropping off student within the selected primary school zone in Selangor.

Table 1. Road crash by area type

\begin{tabular}{|l|r|r|r|r|}
\hline & \multicolumn{4}{|c|}{ Type of road accident } \\
\hline Type of area & Fatal & Serious & Minor & Total \\
\hline Residential & 513 & 262 & 416 & 1,191 \\
\hline Office & 67 & 50 & 70 & 187 \\
\hline Shopping & 147 & 104 & 224 & 475 \\
\hline Industrial/Construction & 225 & 66 & 94 & 385 \\
\hline Bridge/Foot bridge & 127 & 35 & 83 & 245 \\
\hline School & 70 & 72 & 117 & 259 \\
\hline Others & 5,421 & 2,889 & 4,523 & 12,833 \\
\hline Total & 6,570 & 3,478 & 5,527 & 15,575 \\
\hline
\end{tabular}

\section{Safety effect of Drop-off and Pick-up Zone}

The built environment of urban areas can have a strong impact on traffic safety. Wide arterial roadways which are common in suburban areas of North American cities, arterial-oriented commercial developments and big box stores have been associated with increased incidences of collisions and injuries (Dumbaugh \& Rae, 2009).

A study in Baltimore, Clifton and Kreamer-Fults (2007) carried out a study to identify relationships between the built environment and pedestrian crashes. The study used presence of a driveway for student drop-off, presence of recreational facilities, presence of off-street parking, and presence of school set back from the road as variable for built environment. Other road characteristics such as road width, posted speed limit, and traffic volumes were also used in this study. The study (Clifton \& Kreamer-Fults, 2007) found that both the presence of recreation facilities and the presence of driveways are statistically significant. The presence of recreation facilities is positively associated with higher aggregate crash severity for the school zones but the presence of driveways has the opposite effect.

Potentially risky student drop-off behaviours by private vehicle drivers are frequently observed around schools which may contribute to collision risk (Rothman et al., 2017). Based on the study, the most common risky behaviours observed were dropping children at the opposite side of the road from schools (79\%) and reversing dangerously (64\%). Designated drop-off areas were associated with fewer adults crossing at uncontrolled midblock locations, and fewer adults and children crossing between parked cars. In this study (Rothman et al., 2017), designated drop-offs were found to be protective for several risky driving behaviours and pedestrians crossing at uncontrolled locations mid-block as well as between parked cars. 
DEVELOPMENT

Vol. 9, No. 3, 2020, E-ISSN: 2226-6348 @ 2020 HRMARS

\section{Methodology}

A total of 30 schools was chosen for this study which is based on school type, area type and road type. These schools were chosen based on high-risk school provided by the Ministry of Education. For this study, the primary data collection is through on-site observation by a trained researcher and research assistant. The data were collected in the afternoon after the school hour was over for the morning session. Due to variation of the actual time the school end, the duration of observation is 30 minutes from the actual time school end to standardized the data collection and ensure the similarity of data. The risk ratio for pedestrian motor-vehicle crashes within 150 $\mathrm{m}$ of a school was almost 6 times higher than that for distances $>450 \mathrm{~m}$ from a school (Rothman et al., 2017), hence the data will be collected within $50 \mathrm{~m}$ radius from the school gate or the school entrance. If there is more than one entry of the school, the on-site observation was carried out at all school entrances.

\section{Finding \& Discussion}

As mentioned in previous section, there were 30 primary schools selected for this study. Out of these 30 schools only 11 schools with the presence of D\&P. The observation on-site also shows that, some schools are using physical separation such as median kerb or fence to separate the D\&P area with the main road.

Table 2 shows the school characteristic with the presence of D\&P according to city, road type and area type. From the table it can observed that most school with D\&P availability located on primary street road, where there were three (3) school located on federal/state road and only 1 school located on local street.

Table 2. The school characteristic with presence of D\&P

\begin{tabular}{|l|l|l|l|}
\hline School Name & City/District & Road Type & Area Type \\
\hline SK Teluk Gadong & Klang & Primary street & Urban \\
\hline SK Sungai Udang & Klang & Primary street & Urban \\
\hline SK Tambak Jawa & Jeram & Federal/State road & Rural \\
\hline SK Sungai Haji Dorani & Sungai Besar & Primary street & Rural \\
\hline SK Tanjung Karang & Tanjong & Federal/State road & Rural \\
\hline SJK@ Ying Wah & Kapar & Federal/State road & Rural \\
\hline SJK@ Pandamaran B & Pelabuhan Klang & Primary street & Urban \\
\hline SK Seksyen 6 Shah Alam & Shah Alam & Primary street & Urban \\
\hline SK Putra Height 2 & Subang Jaya & Local street & Rural \\
\hline SK Pusat Bandar Puchong 2 & Puchong & Primary street & Urban \\
\hline SK Bukit Rimau & Shah Alam & Primary street & Rural \\
\hline
\end{tabular}

From the on-site observation, the locations where the parents or guardian pick-up the school children with their vehicle was categories into three categories. D\&P is defined as area beyond the road reserve or within the school boundary that is dedicated for dropping off and picking up school children by private vehicles, vans and school buses. D\&P usually located nearest to the school main entrance and parallel to the main road. While nearside is pick-up area not within the 
Vol. 9, No. 3, 2020, E-ISSN: 2226-6348 @ 2020 HRMARS

D\&P area and farside is pick-up area where opposite the school entrance and school children required to cross the main road.

The school children's pick-up vehicle location distribution is shown in Table 3. In general, it can be observed the D\&P utilization varies at these eleven (11) schools. The highest D\&P utilization is observed at SK Tambak Jawa with $86.1 \%$ and the lowest is at SK Bukit Rimau with only $19.9 \%$ rate of utilization. For the rest of nine (9) schools the utilization rate is between $28.3 \%$ to $78.4 \%$ and the average utilization rate for these eleven (11) schools is $51.9 \%$. It is also important to highlight that, there are two (2) schools with no vehicle pick-up the school children at the farside.

Table 3. The school children's pick-up vehicle distribution

\begin{tabular}{|l|r|r|r|r|r|}
\hline School Name & \multicolumn{1}{l|}{ D\&P } & \multicolumn{1}{l|}{ larside } & Nearside & Total & \% D\&P Utilization \\
\hline SK Teluk Gadong & 53 & 8 & 90 & 151 & $35.1 \%$ \\
\hline SK Sungai Udang & 116 & 36 & 29 & 181 & $64.1 \%$ \\
\hline SK Tambak Jawa & 87 & 0 & 14 & 101 & $86.1 \%$ \\
\hline SK Sungai Haji Dorani & 57 & 25 & 9 & 91 & $62.6 \%$ \\
\hline SK Tanjung Karang & 129 & 41 & 54 & 224 & $57.6 \%$ \\
\hline SJKC Ying Wah & 58 & 2 & 14 & 74 & $78.4 \%$ \\
\hline SJKC Pandamaran B & 54 & 40 & 97 & 191 & $28.3 \%$ \\
\hline SK Seksyen 6 Shah Alam & 60 & 45 & 3 & 108 & $55.6 \%$ \\
\hline SK Putra Height 2 & 56 & 28 & 75 & 159 & $35.2 \%$ \\
\hline SK Pusat Bandar Puchong 2 & 135 & 0 & 38 & 173 & $78.0 \%$ \\
\hline SK Bukit Rimau & 32 & 55 & 74 & 161 & $19.9 \%$ \\
\hline Total & 837 & 280 & 497 & 1614 & $51.9 \%$ \\
\hline
\end{tabular}

In contrast with the study at 100 schools in Canada (Rothman L, 2017), over half (58\%) of school had designated drop off areas. This show that the availability of D\&P in Selangor in this study is less than study conducted in Canada. Although there are guidelines (JKR, 2015; PBIC 2007) recommends the designated car drop-off areas in school zone, however, there has been no work previously done to examine how these areas improve safety (PBIC, 2007; Parisi \& Hondorp, 2005).

A study by Rothman L. (2017), managed to found that, designated drop-offs were found to be protective for several risky driving behaviours and pedestrians crossing at uncontrolled locations mid-block as well as between parked cars. The same study also concluded that designated car drop-off areas are a low-cost modification to the built environment that can and should be implemented at every school to be done simultaneously with targeted strategies to ultimately reduce vehicular traffic and increase active school transportation.

Drop-off and pick up location at safe point ensure the safety of school children. Similar to this study, a study in Thailand (Sattanon, \& Upala, 2018) shows that parents mostly parked their cars and dropped their children off in front of the school gate (35\%). Besides than this $24.3 \%$ of parents parked and dropped their children at the sidewalk in front to school which is similar to nearside in this study context. Hence this shows that parents do feel the risk of dropping their 
children in front and nearside of school is lesser and safer. However, in contrast to this, the most common risky behaviours observed were dropping children at the opposite side of the road from schools (79\%) and walking across at uncontrolled midblock locations (Rothman, 2017).

\section{Conclusion \& Recommendation}

As a conclusion, the study found D\&P are only available at 11 schools that out of 30 selected primary schools. In terms of utilization of D\&P at these 11 schools, $52 \%$ of the observed school children used this facility. At school with D\&P also the remaining school children were picked up by their vehicles outside of the D\&P area with $31 \%$ at nearside of the school and $17 \%$ at the far side of the school. In this study, it shows that the D\&P utilization for dropping and picking up school children can be further increase if parents/bus drivers do not wait in D\&P. With the high and the effective D\&P utilization, it will lower the risk of school children involved in an accident while crossing the road.

International practices could be adopted with providing the school children parents and guardian education and information on the best practice to use the D\&P effectively hence directly will increase the D\&P utilization. Besides than this, signage could be put up in the D\&P zone to give reminder to parents and guardian to only use the zone for only pick-up and drop-off not to use as waiting area with this will opportunity for more school children to utilize the D\&P zone.

\section{Acknowledgement}

The authors would like to express their sincerest appreciation to the Director-General of the Malaysian Institute of Road Safety Research (MIROS), and the Director of Road Engineering and Environment Research Center (REER), for extending their full support in conducting this study.

\section{Corresponding Author}

Sharifah Allyana Syed Mohamed Rahim

Malaysian Institute of Road Safety Research, Lot 125-135, Jalan TKS 1, Taman Kajang Sentral, 43000, Kajang, Selangor, Malaysia.

Email: allyana@miros.gov.my

\section{References}

Clifton, K. J., \& Kreamer-Fults, K. (2007). An examination of the environmental attributes associated with pedestrian-vehicular crashes near public schools. Accident Analysis and Prevention, 39(2007), 708 - 715.

Sattanon, K., \& Upala, P. (2018). Evaluation of risk factor for children during drop-off and pick-up time around the primary school in Thailand. The Open Transportation Journal, 12(2018), $12,301-318$.

Dumbaugh, E., \& Rae, R. (2009). Safe urban form: Revisiting the relationship between community design and traffic safety. Journal of the American Planning Association, 75(2009), 309-329.

Rothman, L., Buliung, R., Howard, A., Macarthur, C., \& Macpherson, A. (2017). School environments and social risk factors for child pedestrian-motor vehicle collisions: a casecontrol study. Accident Analysis and Prevention. 98(2017), 252-258. 
INTERNATIONAL JOURNAL OF ACADEMIC RESEARCH IN PROGRESSIVE EDUCATION AND

DEVELOPMENT

Vol. 9, No. 3, 2020, E-ISSN: 2226-6348 @ 2020 HRMARS

Utusan Malayasia. (2009), retrieved from

http://ww1.utusan.com.my/utusan/info.asp?y=2009\&dt=0725\&pub=Utusan_Malaysia\&s ec=Dalam_Negeri\&pg=dn_34.htm 